\title{
Thermochemical sulfate reduction in fossil Ordovician deposits of the Majiang area: Evidence from a molecular-marker investigation
}

\author{
WANG GuangLi ${ }^{1 *}$, LI NingXi ${ }^{1}$, GAO Bo $^{2}$, LI XianQing $^{3}$, SHI ShengBao ${ }^{1} \&$ WANG TieGuan ${ }^{1}$ \\ ${ }^{1}$ State Key Laboratory of Petroleum Resources and Prospecting, and Department of Organic Geochemistry and Environmental Science, College \\ of Geosciences, China University of Petroleum, Beijing 102249, China; \\ ${ }^{2}$ Petroleum Exploration and Production Research Institute, SINOPEC, Beijing 100083, China; \\ ${ }^{3}$ State Key Laboratory of Coal Resources and Safe Mining, China University of Mining and Technology, Beijing 100083, China
}

Received December 10, 2012; accepted March 25, 2013; published online May 7, 2013

\begin{abstract}
The main reservoirs of Majiang fossil deposits consist of the Silurian Wengxiang group, dominantly sandstones, and the Ordovician Honghuayuan formation, dominantly carbonate rocks, and the Lower Cambrian Niutitang Formation mudstones serve as the major source rocks. Thermochemical sulfate reduction (TSR) might have taken place in the Paleozoic marine carbonate oil pools, as indicated by high concentrations of dibenzothiophenes in the extracts (MDBT=0.27-4.32 $\mu \mathrm{g} / \mathrm{g}$ extract, and MDBT/MPH= 0.71-1.38). Hydrocarbons in the Pojiaozhai Ordovician carbonate reservoirs have undergone severe TSR and are characterized by higher quantities of diamondoids and MDBT and heavier isotopic values $\left(\delta^{13} \mathrm{C}=-28.4 \%\right)$. The very large amounts of dibenzothiophenes might be products of reactions between biphenyls and sulfur species associated with TSR.
\end{abstract}

solid bitumen, adamantane, dibenzothiophene, comprehensive two-dimensional gas chromatography/time-of-flight mass spectrometry (GC×GC/TOFMS), thermochemical sulfate reduction (TSR), maturation

Citation: Wang G L, Li N X, Gao B, et al. Thermochemical sulfate reduction in fossil Ordovician deposits of the Majiang area: Evidence from a molecular-marker investigation. Chin Sci Bull, 2013, 58: 3588-3594, doi: 10.1007/s11434-013-5843-x

Marine oil seepage and bitumen occur widely on the Yangtze Platform, South China, and they open a "window" for geologists to understand thermal history and hydrocarbon accumulation. Bitumen, or so-called solid bitumen, is the product of temperature and pressure changes in the subsurface reservoir, external gas injection, microbe attack or interaction with inorganic minerals, and it could be formed from diagenesis to metagenesis [1]. The processes include bacterial sulfate reduction (BSR; $0-80^{\circ} \mathrm{C}$ ) [2], biodegradation $\left(\leqslant 80^{\circ} \mathrm{C}\right)$ [3], thermal cracking $\left(\geqslant 170^{\circ} \mathrm{C}\right)$ [4], thermochemical sulfate reduction $\left(\mathrm{TSR} ;>100^{\circ} \mathrm{C}\right)$ [5-7] and deasphalting [8,9].

Petroleum exploration has been carried out in eastern Guizhou province for decades and has resulted in the discovery of the Majiang fossil reservoir and the Kaili remnant reservoir. In the present study, we have addressed the origin

*Corresponding author (email: sydxwgl@yahoo.cn) of bitumen by isotopic and molecular marker analysis, and the results would be valuable in understanding petroleum accumulation and destruction.

\section{Geological setting}

The study area is located in southeastern Guizhou, Upper Yangtze Platform, between Qianzhong Paleo-uplift and Xuefeng Uplift, and it includes Duyun, Majiang, Kaili and Danzhai. The main source-rock horizon is the Lower Cambrian Niutitang Formation, dominanted by black mudstones, while the major reservoirs include the sandstones of the Silurian Wengxiang Group and the carbonate rocks of the Ordovician Honghuayuan Formation. The cap rocks consist of the Honghuayuan Formation, the Dawan Formation and the fourth member of the Wengxiang Group [10-13]. Geological surveys have shown that petroleum accumulation 
and subsequent destruction took place in the Caledonian Period [11], but the evidence from fluid inclusions indicates that hydrocarbon accumulation lasted until the Indosinian and that the hydrocarbons were destroyed in the Yanshanian to Himalaya Periods [14]. Bitumen and oil seepage have also been found in the Permian strata and are associated with the Lower Permian Qixia Formation source rocks [12].

\section{Samples and methods}

Ten bitumen and four oil-seepage samples were collected in the Majiang and Kaili areas. Bitumen samples were powdered and extracted in a Soxhlet apparatus with $\mathrm{CHCl}_{2}$ for $24 \mathrm{~h}$. The extracts and oils were deasphaltened and then fractionated using column chromatography (silica gel/alumina, $3: 1)$ into saturate, aromatic and resins. The sequential elution solvents were $n$-hexane, $\mathrm{CH}_{2} \mathrm{Cl}_{2}$ with $n$-hexane (7:3), and $\mathrm{CHCl}_{3}$ with $\mathrm{CH}_{3} \mathrm{OH}(1: 1)$. The carbon isotopic ratios were measured for the whole oil/extract and each fraction.

The saturated and aromatic hydrocarbons were analyzed using gas chromatography-mass spectrometry (GC-MS) with an Agilent 6890 gas chromatograph coupled to an Agilent $5973 \mathrm{~N}$ mass spectrometer. For saturate analysis, a DB-5MS column (60 $\mathrm{m} \times 0.25 \mathrm{~mm}, 0.25 \mu \mathrm{m}$ film thickness) was used, with the oven temperature programmed from $100^{\circ} \mathrm{C}(1 \mathrm{~min})$ to $320^{\circ} \mathrm{C}$ (held $20 \mathrm{~min}$ ) at $4^{\circ} \mathrm{C} / \mathrm{min}$. For aromatics, a BPX5 column (30 $\mathrm{m} \times 0.22 \mathrm{~mm}, 0.25 \mu \mathrm{m}$ film thickness) was used, with the oven temperature programmed from $80^{\circ} \mathrm{C}(1 \mathrm{~min})$ to $320^{\circ} \mathrm{C}$ (held $20 \mathrm{~min}$ ) at $3^{\circ} \mathrm{C} / \mathrm{min}$. He carrier gas was maintained at a constant flow of $1 \mathrm{~mL} / \mathrm{min}$. The temperatures of the injector and transfer line were 300 and $280^{\circ} \mathrm{C}$, respectively. The mass spectrometer was operated in full scan mode or selected ion monitoring (SIM) mode, with an ionization energy of $70 \mathrm{eV}$. Internal standards of $\mathrm{d}_{4}$-24-ethyl, $5 \alpha(\mathrm{H}), 14 \alpha(\mathrm{H}), 17 \alpha(\mathrm{H})$-cholestane $(20 \mathrm{R})$ and $\mathrm{d}_{16}$-adamantane were added to the saturates to measure the concentrations of steranes and diamondoids, respectively, while $\mathrm{d}_{8}$-dibenzothiophene was added to the aromatics to assess the concentrations of dibenzothiophenes.

$\mathrm{GC} \times \mathrm{GC} / \mathrm{TOFMS}$ analysis was performed on an Agilent 7890A gas chromatograph coupled to a Pegasus 4D time-offlight mass spectrometer. The nonpolar (HP-5ms; $5 \%$ phenyl equivalent) phase column $(30 \mathrm{~m} \times 0.25 \mathrm{~mm}$ ID $\times 0.25 \mu \mathrm{m} \mathrm{df})$ was selected for the $1 \mathrm{D}$ phase, and a polar (BPX50; $50 \%$ phenyl equivalent) phase column $(2 \mathrm{~m} \times 0.1 \mathrm{~mm}$ ID $\times 0.1 \mu \mathrm{m}$ df) was used for the $2 \mathrm{D}$ phase. Helium was used as carrier gas with a constant flow of $1.5 \mathrm{~mL} / \mathrm{min}$. The samples were injected into a heated $\left(300^{\circ} \mathrm{C}\right)$ split/splitless injector, with a split ratio of 10:1. The GC oven was programmed from $80^{\circ} \mathrm{C}$ (held $1 \mathrm{~min}$ ) to $120^{\circ} \mathrm{C}$ at $10^{\circ} \mathrm{C} / \mathrm{min}$ (held $1 \mathrm{~min}$ ), and then heated to $315^{\circ} \mathrm{C}$ at $2{ }^{\circ} \mathrm{C} / \mathrm{min}$ (held $20 \mathrm{~min}$ ). The second oven ramped from $90^{\circ} \mathrm{C}$ (held $1 \mathrm{~min}$ ) to $130^{\circ} \mathrm{C}$ at $10^{\circ} \mathrm{C} / \mathrm{min}$ (held $1 \mathrm{~min}$ ), and then heated to $325^{\circ} \mathrm{C}$ at $2^{\circ} \mathrm{C} / \mathrm{min}$ (held 20 min). The modulator temperature offset was $30^{\circ} \mathrm{C}$ relative to the GC oven, and the modulation period was $8 \mathrm{~s}$.

\section{Results and discussion}

\subsection{Indigenity and source of the bitumen and oil seepage}

Since the bitumen and oil samples were collected from a surface outcrop, it is necessary to distinguish whether they were contaminated by hydrocarbons that had migrated from younger deposits. All the samples contain high quantities of extracts ranging from 103 to $542 \mathrm{ppm}$ (Table 1), except for three samples, DY-B-2, LS-B-4 and MJ-B-4, with low quantities of extracts in the range 9-84 ppm. Recent studies suggest that the concentrations of diamondoids are maturitydependent, increasing with thermal maturation up to a $R_{\mathrm{o}}$ of $4.0 \%[15,16]$. Increasing thermal maturation, through oil cracking and TSR, results in decreasing biomarker concentrations and increasing diamondoid concentrations [17]. Consequently, the concentrations of biomarkers and diamondoids, when coupled together, provide a novel and convenient way to identify mixed oils with different maturities or samples contaminated by hydrocarbons that had migrated (Figure 1). Figure 1 can be divided into three zones for the oils and hydrocarbons. Zone A contains high concentrations of biomarkers, here $\mathrm{C}_{29} \alpha \alpha \alpha, 20 \mathrm{R}$ sterane, and low concentrations of diamondoids, here 3-+4-methyl diamantanes, associated with oils derived from kerogen cracking. Zone B contains low concentrations of biomarkers and high concentrations of diamondoids, which are related to hydrocarbons derived from oil cracking. However, Zone M contains relatively high concentrations of both biomarkers and diamondoids. This is the result of oil mixing or of high-maturity hydrocarbons contaminated by migration of low-maturity hydrocarbons. It can be seen that most of our bitumen and oil samples fall in Zone B. This indicates that they are high-maturity hydrocarbons with no mixing or contamination. In particular, the solid bitumen DY-B-1 produced from the carbonate-rock reservoir of the Lower Ordovician Honghuayuan Formation in Pojiaozhai contains an extremely high diamondoid concentration of $4240 \mathrm{ppm}$. This is 1-2 orders of magnitude higher than the concentrations in other samples, revealing that intense oil cracking or TSR took place [17]. However, samples LS-B-4 and MJ-B-4 fall in Zone M. This reveals that these two samples were contaminated by hydrocarbons that had migrated, and these two samples are ignored in the following discussion.

The bitumen and oil seepage samples could be classified into two groups (Table 1). One group contains isotopically light samples with whole-oil carbon-isotope signatures mostly less than $-30 \%$ o. This group occurs in Ordovician, Silurian and Devonian strata. The other group contains isotopically heavy samples with the whole-oil carbon-isotope values around $-28 \%$. They are produced in Permian strata. Based on previous reports $[10-13,18-20]$, the first group is generated 


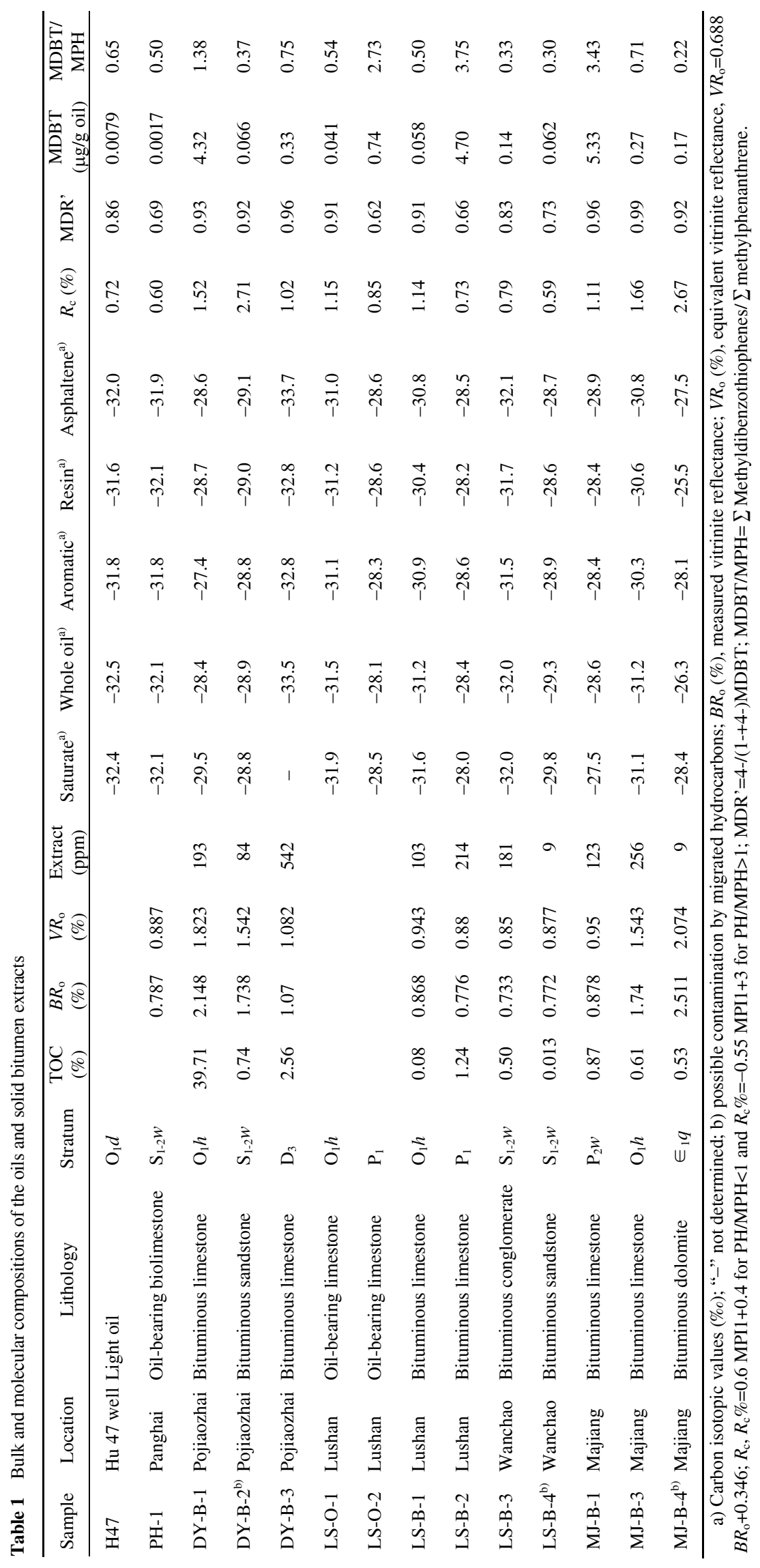




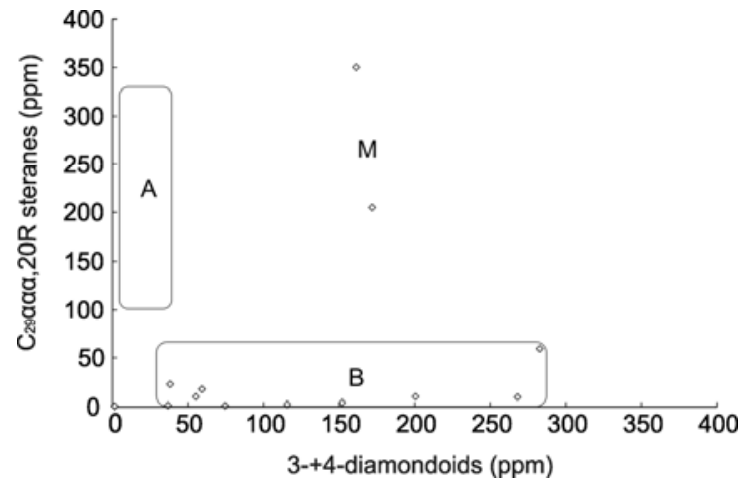

Figure 1 Correlation between biomarker (stigmastane) and diamondoid (3-+4-methyl diamantane) concentration in a series of oil and bitumen extracts from the Majiang and Kaili area. Sample DY-B-1 is not shown in the figure. In that sample, the concentration of 3-+4-methyl diamantine is $4240 \mathrm{ppm}$, and that of $\mathrm{C}_{29} \alpha \alpha \alpha, 20 \mathrm{R}$ sterane is $4.8 \mathrm{ppm}$.

by Lower Cambrian Niutitang Formation mudstones, and the second group is derived from Lower Permian carbonate rocks. One exception is the sample DY-B-1, occurring in Ordovician reservoirs. This sample is rich in ${ }^{13} \mathrm{C}$.

None of the oil seepage or bitumen samples contained terrestrial-plant-associated biomarkers such as oleanane and tetracyclic diterpene, providing circumstantial evidence that they were not related to Mesozoic or Tertiary source rocks.

It has been shown that marine source rocks, including those of the Lower Cambrian Niutitang Formation, are predominately mudstones on the Yangtze Platform, while carbonate source rocks only appear in the Lower Permian Qixia-Maokou Formations. The Niutitang source rocks in the Majiang area contain abundant organic matter, with TOC ranging from $17 \%$ to $22 \%$, and are dominated Type II kerogen [19]. Therefore, the oil seepage and bitumen in the Majiang-Kaili area came from the mudstones of the Niutitang Formation, while the bitumen in the Permian strata originated from Lower Permian carbonate source rocks. The dibenzothiophene to phenanthrene ratio (DBT/PH), the methyl dibenzothiophene to methylphenanthrene ratio (MDBT/ $\mathrm{MPH}$ ), and the pristane to phytane ratio can be used to infer crude-oil source-rock depositional environments and lithologies [21]. Because the phenanthrenes are readily lost from surface outcrops, leading to DBT/PH increases [22], we use MDBT/MPH rather than DBT/PH. It is suggested that the oil seepage and bitumen derived from Permian carbonate source rocks have higher MDBT/MPH ratios, greater than 2 and ranging from 2.7 to 3.7. Except for sample DY-B-1, the MDBT/MPH ratios of all the bitumen and oils originating from the Lower Cambrian Niutitang Formation are less than unity (Table 1).

\subsection{Thermal maturation and origin of the solid bitumen}

Because the solid bitumen could be formed from diagenesis through catagenesis to metagenesis, it is vital to determine the maturation of the solid bitumen in order to understand its origin. It is suggested that the equivalent vitrinite reflectance $\left(V R_{\mathrm{o}}\right)$ of Paleozoic bitumen in the Kaili area ranges from $0.85 \%$ to $0.94 \%$, falling in the oil generation window; whereas VRo of Paleozoic bitumen in the Majiang area ranges from $1.0 \%$ to $2.1 \%$, falling in the highly-mature to post-mature stage.

Most molecular maturity parameters have dynamic ranges that correspond to the early stages of kerogen evolution. Very few parameters provide reliable maturity estimates in the high-temperature zone. However, the calculated vitrinite reflectance $\left(R_{\mathrm{c}} \%\right)$, MDR or MDR' parameters show significant potential for maturity assessment at elevated maturity levels [23]. MDR shows relatively small increases with maturity in the $0.53 \%-1.1 \% R_{\mathrm{o}}$ range. At higher maturity, MDR increases more rapidly. This rapid change occurs in a vitrinite reflectance range of approximately $1.1 \%-1.2 \% R_{0}$, which marks the conventional onset of "oil-to-gas conversion", beyond which only light oil/gas-condensate occurs [24,25]. The calculated vitrinite reflectance $R_{\mathrm{c}}, \mathrm{MDR}$ and MDR' are roughly consistent with $V R_{\mathrm{o}}$ (Table 1 ).

Petroleum alteration, such as thermal cracking or TSR, is a key process in the destruction of an oil pool and formation of bitumen at elevated temperatures. It could be responsible for the high-maturity Ordovician bitumen in the Majiang area.

\subsection{Molecular marker evidence for TSR in the fossil oil reservoirs}

Thermochemical sulfate reduction (TSR) is the abiological reduction of sulfate by hydrocarbons in reservoirs close to anhydrite at high temperatures [26]. Because the oxidation state of sulfur ranges from +6 to -2 , during the reduction of sulfate to sulfide, the sulfur in reactions includes elemental sulfur and other sulfur intermediates such as polysulfides and thiosulfates [27-32]. Many sour gas and oil reservoirs in the world are considered to be the result of TSR [7,33,34]. The minimum temperature required to initiate TSR was controversial for many years. Recent work suggests that TSR begins in the range $127-140^{\circ} \mathrm{C}$, depending on the hydrocarbon compositions [35]. It is observed that the bitumen from carbonate reservoirs of Ordovician and Devonian age in the Majiang area, including DY-B-1, DY-B-3 and MJ-B-3, contains abundant dibenzothiophenes Their concentrations of MDBT are in the range $0.27-4.32 \mu \mathrm{g} / \mathrm{g}$ extract, and the MDBT/MPH ratios are in the range 0.71-1.38, far greater than those in the reservoirs of the Majiang Silurian sandstone and the Kaili Ordovician carbonate rock (MDBT= $0.0017-0.14 \mu \mathrm{g} / \mathrm{g}$ extract, MDBT/MPH=0.33-0.65). The thiophene-rich oils could originate from marine carbonate source rock [36] or from limestone, muddy carbonate rock or siliceous/phosphate source rock [21], as well as from some saline, lacustrine carbonate source rock [37,38]. However, the mudstone source rocks of the Niutitang Formation could not generate much sulfur-rich oil; in addition, the other oil and bitumen derived from Niutitang Formation 
contain much smaller amounts of dibenzothiophenes. Furthermore, the MDBT/MPH ratios would not be influenced significantly by thermal stress [39]. Consequently, the occurrence of dibenzothiophenes is not controlled by depositional environments or source rocks, but by secondary alteration of petroleum in the reservoirs. However, thermal cracking would reduce the amounts of organic sulfur compounds [35]. So we infer that the high abundance of dibenzothiophene compounds in Ordovician solid bitumen of the Majiang area is the result of TSR of hydrocarbons in carbonate-rock reservoirs. The Majiang Silurian sandstone reservoir contains no sulfate, while the paleotemperature of the Kaili Ordovician strata has not exceeded $103^{\circ} \mathrm{C}$. Therefore, they could not stimulate TSR.

Although petroleum in the marine carbonate rocks of the
Majiang area has undergone TSR, the intensity is different because of the varying temperatures of the reservoir. The concentrations of MDBT in samples DY-B-3 and MJ-B-3 are in the range $0.27-0.33 \mu \mathrm{g} / \mathrm{g}$ extract, and MDBT/MPH ratios are in the range $0.71-0.75$; thus the intensity of TSR is minor. It is notable that their concentrations of biomarkers are very low, but asphaltene is near $100 \%$ in the extract. We infer that, besides TSR, the reservoir may have experienced gas injection, leading to the formation of pure asphaltene. This is analogous to adding excess $n$-hexane to remove the asphaltene of oil in the laboratory. Nearly all of the biomarkers, including diamondoids, extract into the oil, leaving little in the asphaltene. Nevertheless, the equivalent vitrinite reflectance $V R_{\mathrm{o}}$ of the Ordovician Honghuayuan Formation bitumen in Pojiaozhai is $1.8 \%$. There the highest paleotem-
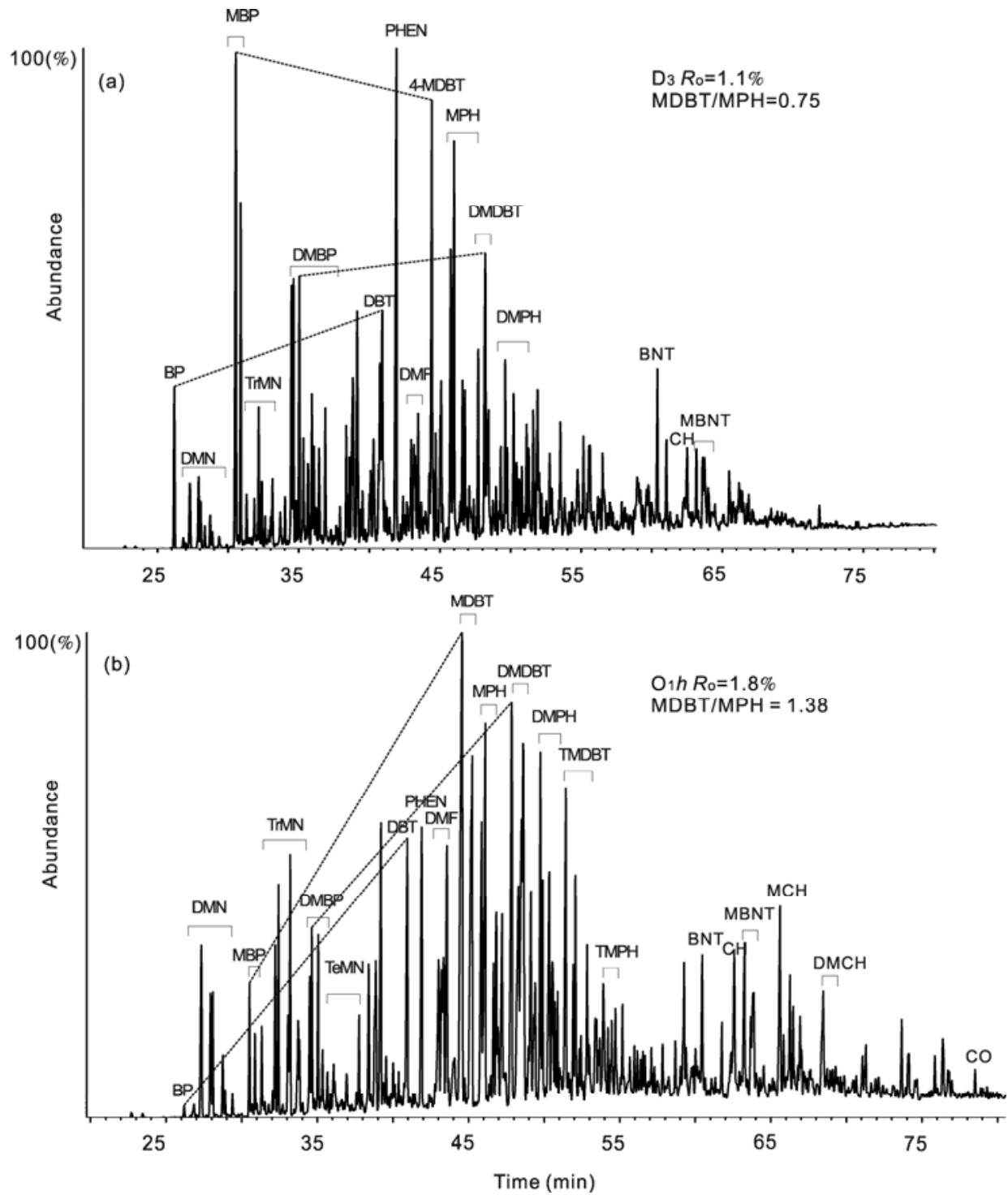

Figure 2 GC-MS TIC of aromatics in the extracts from two solid bitumens from Pojiaozhai. BP, biphenyl; MBP, methyl diphenyl; DMBP, dimethyl diphenyl; DMN, dimethylnaphthalene; TrMN, trimethylnaphthalene; TeMN, tetramethylnaphthalene; PH, phenanthrene; MPH, methylphenanthrene; DMPH, dimethylphenanthrene; DBT, dibenzothiophene; MDBT, methyl dibenzothiophene; DMDBT, dimethyl dibenzothiophene; TMDBT, trimethyl dibenzothiophene; BNT, benzonaphthothiophene; MBNT, methyl benzonaphthothiophene. 
perature reached about $140-150^{\circ} \mathrm{C}$, and TSR is intense. This is shown in the molecular marker compositions. For example, DY-B-1 contains extremely abundant diamondoids, including adamantanes, diamantanes and triamantanes. Furthermore, dibenzothiophene compounds are very abundant (Figure 2); the concentration of MDBT is high, up to 4.32 $\mu \mathrm{g} / \mathrm{g}$ extract, and MDBT/MPH>1 (Table 1 ). In addition, the carbon isotopic values of the extract and saturate are $-28.4 \%$ o and $-29.5 \%$, respectively, much heavier than they are in samples that have not experienced TSR.

Examination of a well-documented case history in a western Canada sedimentary basin using two-dimensional gas chromatography $(\mathrm{GC} \times \mathrm{GC})$ has produced a useful tool for fingerprinting TSR-affected petroleum fluids [40]. GCX GC chromatograms of oil from the Upper Devonian Nisku reservoir in the Alberta Basin, which had not suffered TSR, include $n$-alkanes, alkyl cyclohexane, cyclopentane, alkylbenzene and a few benzofurans and naphthalenes; while GCx GC chromatograms of oil that had suffered intense TSR were dominated organic sulfur compounds (OSCs) such as benzothiophene and dibenzothiophene. In the $\mathrm{GC} \times \mathrm{GC}$ chromatograms of DY-B-1, dibenzothiophene is a major compound, and benzonaphthothiophene and other OSCs ap- peared (Figure 3), evidence that the hydrocabons had undergone TSR.

It is very interesting that the bitumen sample DY-B-3 from the Pojiaozhai Upper Devonian strata contains abundant biphenyl compounds and a low abundance of dibenzothiophenes, whereas DY-B-1 from the Lower Ordovician Honghuayuan Formation, which experienced the strongest TSR, has abundant dibenzothiophene compounds but only small amounts of biphenyl compounds (Figure 2). It seems that there are transformations of BP to DBT, MBP to MDBT, and DMBP to DMDBT during TSR. In other words, sulfur in the reduced state may react with biphenyl compounds and transform them to dibenzothiophene compounds. This process has been conducted in the laboratory [41].

\section{Conclusions}

The solid bitumen from the Lower Ordovician Honghuayuan Formation carbonate reservoirs in the Majiang area includes abundant dibenzothiophenes. They were not derived from marine carbonate source rock, and they were not influenced by BSR or biodegradation. In addition, the carbon isotopic
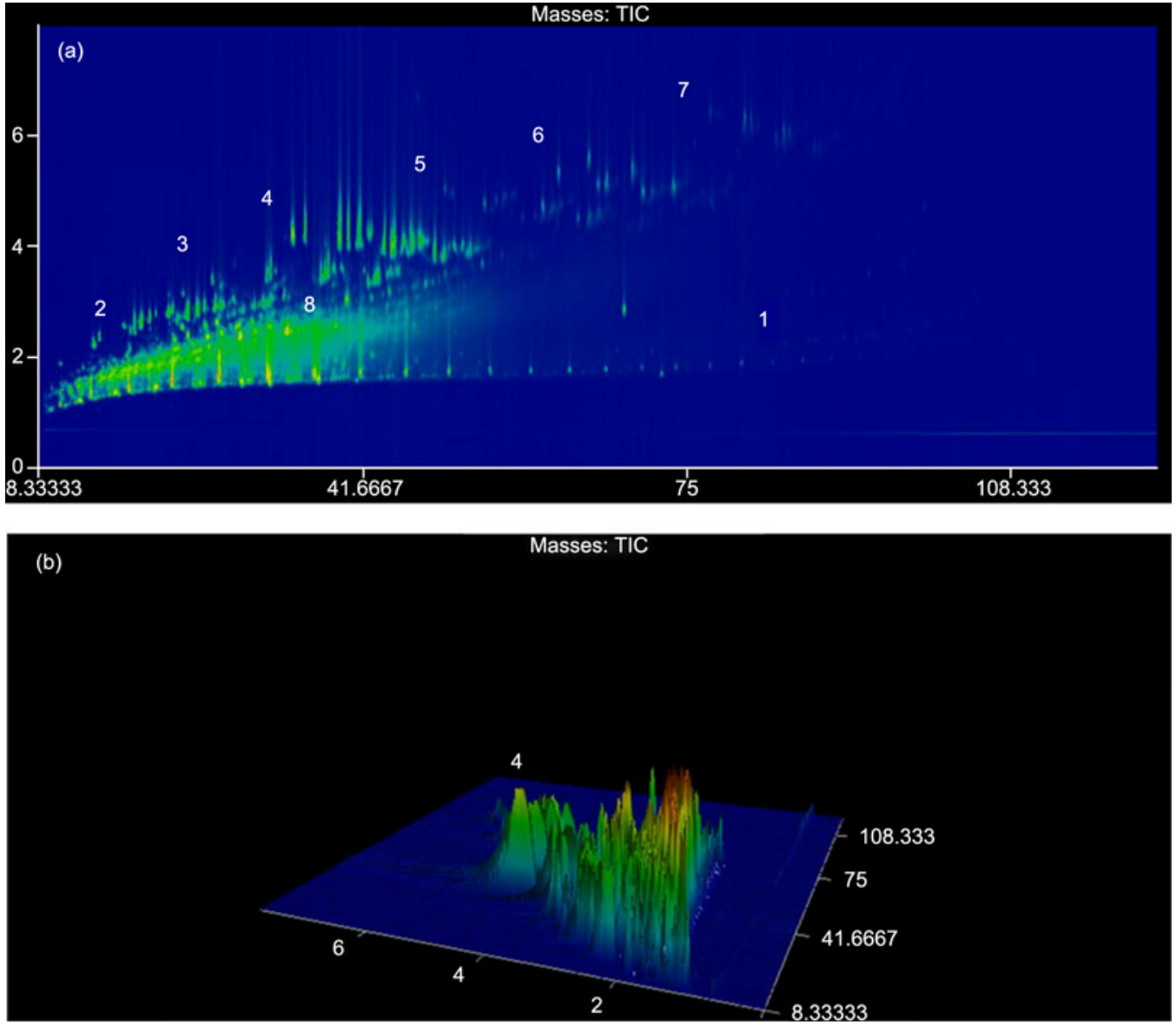

Figure 3 GC $\times$ GC/TOFMS analysis of DY-B-1 extract: (a) contour plot and (b) surface plot. Compound classes are as follows: 1 , $n$-alkanes; 2 , naphthalene; 3 , fluorine; 4 , dibenzothiophene and phenanthrene; 5 and 7 , organic sulfur compounds; 6 , benzonaphthothiophene, 8 , adamantine. 
value is heavy, and diamondoids were high. We argue that the bitumen was the product of TSR. This reveals that TSR is one key factor in the destruction of the Majiang large oil pool.

We thank Dr. Jin Zhijun, Dr. Liu Dongsheng and Zhou Dikang for their help with outcrop investigations, and two anonymous reviewers for comments and suggestions. This work was supported by the State Key Project of Petroleum (2008ZX05005-001-009HZ), the National Natural Science Foundation of China (41172126), the State Key Laboratory of Petroleum Resources and Prospecting (PRP2010-01) and the Science Foundation of China University of Petroleum (LLYJ-2011-05 and KYJJ-2012-01-01).

1 Curiale $\mathbf{J}$ A. Origin of solid bitumen, with emphasis on biological marker results. Org Geochem, 1986, 10: 559-580

2 Machel H G. Bacterial and thermochemical sulfate reduction in diagenetic settings — old and new insights. Sediment Geol, 2001, 140: 143-175

3 Peters K E, Moldowan J M. The Biomarker Guide: Interpreting Molecular Fossils in Petroleum and Ancient Sediments. New Jersey: Prentice-Hall, Englewood Cliffs, 1993

4 Huc A Y, Nederlof P, Debarre R, et al. Pyrobitumen occurrence and formation in a Cambro-Ordovician sandstone reservoir, Fahud Salt Basin, North Oman. Chem Geol, 2000, 168: 99-112

5 Worden R H, Smalley P C. $\mathrm{H}_{2}$ S-producing reactions in deep carbonate gas reservoirs: Khuff Formation, Abu Dhabi. Chem Geol, 1996, 133: 157-171

6 Cai C F, Worden R H, Bottrell S H, et al. Thermochemical sulphate reduction and the generation of hydrogen sulphide and thiols (mercaptans) in Triassic carbonate reservoirs from the Sichuan Basin, China. Chem Geol, 2003, 202: 39-57

7 Ma Y S, Zhang S C, Guo T L, et al. Petroleum geology of the Puguang sour gas field in the Sichuan Basin, SW China. Mar Petrol Geol, 2008, 25: 357-370

8 Bailey N J L, Evans C R, Milner C W D. Applying petroleum geochemistry to search for oil: Examples from Western Canada basin. AAPG Bull, 1974, 58: 2284-2294

9 Wilhelms A, Larter S R. Origin of tar mats in petroleum reservoirs. Part II: Formation mechanisms for tar mats. Mar Petrol Geol, 1994, 11: 442-456

10 Han S Q, Wang S D, Hu W Y. Discovery of Majiang fossil reservoir in eastern Guizhou and its implication to petroleum exploration (in Chinese). Petrol Gas Geol, 1982, 3: 316-326

11 Han S Q, Wang S D. Petroleum generation and catagenesis in the Lower Paleozoic of eastern Guizhou (in Chinese). Petrol Geol Exp, 1983, 5: 3-7

12 Zhang Q, Tenger, Zhang Z R, et al. Source of oil seepage and solid bitumen in the Kaili-Majiang Area (in Chinese). Acta Geol Sin, 2007, 81: 1118-1124

13 Gao L, Liu G Y. Analysis on oil source of lower Palaeozoic crude oil from Kaili area in Guizhou Province (in Chinese). Petrol Geol Exp, 2008, 30: 186-191

14 Xiang C F, Tang L J, Li R F, et al. Episodic fluid activity in the superimposed basin: Evidence from outcrop and fluid inclusion in Majiang fossil reservoir (in Chinese). Sci China Ser D-Earth Sci, 2008, 38 (Suppl): 70-77

15 Wingert W S. GC-MS analysis of diamondoid hydrocarbons in Smackover petroleums. Fuel, 1992, 71: 37-43

16 Wei Z B, Moldowan J M, Jarvie D M, et al. The fate of diamondoids in coals and sedimentary rocks. Geology, 2006, 34: 1013-1016

17 Dahl J E, Moldowan J M, Peters K, et al. Diamondoid hydrocarbons as indicators of oil cracking. Nature, 1999, 399: 54-56

18 Stahl W J. Carbon and nitrogen isotopes in hydrocarbon research and exploration. Chem Geol, 1977, 20: 121-149

19 Liang D G, Guo T L, Chen J P, et al. Distribution of four suits of re- gional marine source rocks (in Chinese). Mar Origin Petrol Geol, 2008, 13: 1-16

20 Liang D G, Guo T L, Chen J P, et al. Geochemical characteristics of four suits of regional marine source rocks, South China (in Chinese). Mar Origin Petrol Geol, 2009, 14: 1-15

21 Hughes W B, Holba A G, Dzou L I P. The ratios of dibenzothiophene to phenanthrene and pristane to phytane as indicators of depositional environment and lithology of petroleum source rocks. Geochim Cosmochim Acta, 1995, 59: 3581-3598

22 Hostettler F D, Kvenvolden K A. Geochemical changes in crude oil spilled from the Exxon Valdez supertanker into Prince William Sound, Alaska. Org Geochem, 1994, 21: 927-936

23 Radke M, Welte D H, Willsch H. Maturity parameters based on aromatic hydrocarbons: Influence of the organic matter type. In: Leythaeuser D, Rullk6tter J, eds. Advances in Organic Geochemistry 1985. London: Pergamon Press, 1986

24 Dzou L I P, Noble R A, Senftle J T. Maturation effects on absolute biomarker concentration in a suite of coals and associated vitrinite concentrates. Org Geochem, 1995, 23: 681-697

25 Wei Z B, Zhang D J, Zhang C L, et al. Methyldibenzothiophenes distribution index as a tool for maturity assessment of source rocks (in Chinese). Geochimica, 2001, 30: 242-247

26 Worden R H, Smalley P C, Oxtoby N H. Gas souring by thermochemical sulfate reduction at $140^{\circ} \mathrm{C}$. AAPG Bull, 1995, 79: 854-863

27 Goldstein T P, Aizenshtat Z. Thermochemical sulfate reduction: A review. J Therm Anal, 1994, 42: 241-290

28 Steinfatt I, Hoffmann G G. A contribution to the thermochemical reduction of $\mathrm{SO}^{2-}$ in the presence of $\mathrm{S}^{2-}$ and organic compounds. Phosphorus Sulfur, 1993, 74: 431-433

29 Wei Z B, Walters C C, Moldowan J M, et al. Thiadiamondoids as proxies for the extent of thermochemical sulfate reduction. Org Geochem, 2012, 44: 53-70

30 Jiang N H, Zhu G Y, Zhang S C, et al. Detection of 2-thiaadamantanes in the oil from Well TZ-83 in Tarim Basin and its geological implication. Chin Sci Bull, 2008, 53: 396-401

31 Jiang N H, Zhu G Y, Zhang S C, et al. The content of methyldibenzothiophenes in oil and its relationship with depositional environment and catagenesis (in Chinese). Geosci Front, 2008, 15: 186-194

32 Cai C F, Li H T. Thermochemical sulfate reduction in the sedimentary basin: A review (in Chinese). Adv Earth Sci, 2005, 20: 1100-1105

33 Orr W L. Changes in sulfur content and isotopic ratios of sulfur during petroleum maturation-study of Big Horn basin Paleozoic oils. AAPG Bull, 1974, 58: 2295-2318

34 Claypool G E, Mancini E A. Geochemical relationships of petroleum in Mesozoic reservoirs to carbonate source rocks of Jurassic Smackover Formation, southwestern Alabama. AAPG Bull, 1989, 73: 904-924

35 Peters K E, Fowler M G. Applications of petroleum geochemistry to exploration and reservoir management. Org Geochem, 2002, 33: 5-36

36 Waldo G S, Carlson R M, Moldowan J M, et al. Sulfur speciation in heavy petroleums: Information from X-ray absorption near-edge structure. Geochim Cosmochim Acta, 1991, 55: 801-814

37 Wang G L, Wang T G, Zhang L Y. Hydrocarbon-generation characteristics for lacustrine carbonate source rocks in Bonan Sag of Jiyang Depression (in Chinese). Acta Petrol Sin, 2007, 28: 62-68

38 Wang G L, Wang T G, Simoneit B R T, et al. Sulfur rich petroleum derived from lacustrine carbonate source rocks in Bohai Bay Basin, East China. Org Geochem, 2010, 41: 340-354

39 Hughes W B, Holba A G, Dzou I P. The ratios of dibenzothiophene to phenanthrene and pristane to phytane as indicators of depositional environment and lithology of petroleum source rocks. Geochim Cosmochim Acta, 1995, 59: 3581-3598

40 Li M, Zhang S C, Jiang C Q, et al. Two-dimensional gas chromatograms as fingerprints of sour gas-associated oils. Org Geochem, 2008, 39: $1144-1149$

41 Klemm L H, Karchesy J J. Dibenzothiophene from biphenyl and derivatives. J Hetero Chem, 1978, 15: 561-563

Open Access This article is distributed under the terms of the Creative Commons Attribution License which permits any use, distribution, and reproduction in any medium, provided the original author(s) and source are credited. 